\title{
Elements of Magical Rituals: A Traditional Practice of North Kerala
}

\author{
P. Vijisha, E. K. Govinda Varma Raja* \\ School of Folklore Studies, University of Calicut, Kerala, India \\ Email: vijivijishap@gmail.com, "govindavarmaraja@gmail.com
}

Received 26 October 2015; accepted 23 November 2015; published 26 November 2015

Copyright (C) 2015 by authors and Scientific Research Publishing Inc.

This work is licensed under the Creative Commons Attribution International License (CC BY). http://creativecommons.org/licenses/by/4.0/

c) (i) Open Access

\begin{abstract}
The strengthening of mental power will help the patients to overcome their unrest. Mental unrest of an individual is the product of the folk which he/she belongs. The folk itself have found out the remedy for it as traditional rituals. The traditional practitioners have developed certain tools and technologies with the help of indigenous knowledge. It was examined with the case studies practised in north Kerala.
\end{abstract}

Keywords

Magical Rituals, Traditional Practice, Indigenous Knowledge

\section{Introduction}

The local history of Payangode region is edited by Balakrishnan mentioned in page No. 206 about the customs and beliefs as revealed to magical rituals such as "Vellam Manthrichozhukkal" (to shower water with chants on the wound). If a boy/girl eats a tasty food without giving to a greedy person or a glutton who sees it, they may curse the boy/girl, which may lead to stomach ache. The treatment for this disease by traditional magician is "Kothikkupidikkal" (to catch the curse of yearning man). There is another witchcraft rendered in the region, "Odivekkal" (to do a black magical ritual against the enemy). The remedy for this is known as "Odikothal" (to destroy the witchcraft of enemies). "Kaivisham" (food given anybody along with some medicine to attract or repel) is a magical custom for attracting the lovers and destroying the enemies [1].

Mandravadhavum Mathavum (Magic and Religion), a book written by C. R. Kerala Varma, explains the basics of magical rituals in Kerala [2]. Mandrika Vinjnanam (Magical lore) by M. V. Vishnu Namboothiri points out different kinds of magical rituals in Kerala [3]. A magical ritual activist Kattumaadam Narayanan in his book "Magical Rituals in Kerala" explains the magical rituals done by elite class [4]. In one of his other books

"Corresponding author. 
“Magical Rituals and Black Magical Rituals”, he compares the magical rituals and black magical rituals [5]. Kerala is very famous in magical rituals but there are no scientific studies about it. It includes Homa (The offering like coconut, rice, plants, grase are burning in the fire as sacred offering), Bali (Animal sacrifice) and Pooja (worship). Apart from all these things, another way of magical ritial is writing magical words on metal foil. It is depicted Yandravidhikal (The proceedings of writing magical words on metal foil with metal pen). All these references prove the prominence of magical rituals in contemporary Kerala [6].

The history of rituals has started with the origin of mankind. A magical ritual is a kind of ritual which is practised everywhere with secret. The rulers of the past in Kerala give the right to do magical rituals as birth right (Cherujanmavakasha) to certain communities. The Malaya community has the traditional right to do magical rituals in north Kerala. Some Brahmin families in north Kerala like Kattumadam and Kalakattu also have the right to do magical rituals. There is a legend on Kadathanad related to the migrations of Brahmin community from Vaikkam to Kadathanad. The main reason of this migration is the conflict between the king Porlathiri and local Brahmins. The local Brahmins deny continuing to do the death rituals of Porlathiri when they become rich. This made enmity to the local Brahmins by the King. So he brought ten Brahmin families from Vaikom, a place in Middle Kerala and gave much respect to the invited Brahmins. He distributed various rights to each and every Brahmin family. The right to do chief tantric rituals in the temples of Kadathanadu was given to Eranchery family. The right to do magical rituals was given to Paroli family and others were given the position of chief priests of temples. A magical ritual is a practical problem solving methodology all over world. It is discussed in books like Golden Bough, written by Sir. James George Frazier. In India, both magic and black magic is being done by the communal folk. Black magic rituals are considered as a part of magical rituals. Black magic is related to certain elements in the society. There is a saying "words have magical power”. This saying itself proves the importance of magical rituals. Practising magical rituals are a traditional occupation for certain communities. So this process is not alienated from the folk.

Magical rituals are related to some other elements in the society. Suppose that an unsolved problem is faced by an individual or a family, they approach an astrologer to solve the problem. After a serious calculation with position of the Zodiac signs, the astrologer suggests some solutions. These solutions are mostly solved by a ritual by al magician. The number of magical ritual practitioners in Kadathanadu region is very high. This is because there are caste based performers like Brahmin, Panan [Malayapaniker], Thiyya, Vishvakarma and Kaniyan. The name of the main magical ritual performers’ family is Parollly Illam. Daily, hundreds of patients visit this family. There are other Brahmins families doing magical rituals such as Erancheryillam in Villlaypally, Kuniyil Illam in Orkatteri, Kunnamagalam Illam in Kuttangaaram and Velliyodu Illam in Thaneerpandhal. Carpenters, weavers and Nair communities are also doing magical ritual performances. To study the different kinds of magical rituals of Kadathanadu, we selected a particular family among the Thiyya community. There was a skilled folk medical practitioner and famous magical ritual performer at Puthuppanam, late Puzhuyil Aandi and his sons Achuthan and Narayanan and their students Kanakadas and Padmanabhan. The observation and participant observation method is applied to collect the data. The magical ritual practices of Kanakadas and Padmanabhan were observed in different context. The tools applied for collecting data are direct observation and interview method. The patients were not ready to reveal their experiences. Anyhow, they agreed to take an interview by the condition of keeping the data secret. So for privacy reasons, names of the informants are not included. Moreover, the magicians are dead against to reveal the secret nature of the magical ritual. Anyhow, the data explain everything. So the following events are examined as a case study.

\section{Events}

The events are classified as five according to its nature.

\subsection{The Application of Intelligence of Magical Performer}

Once a maiden girl of Puthuppanam underwent an unrest regarding oppression from invisible cases, so she expressed different types of indisposition. Hence, the elders of the family visited a nearby astrologer. The astrologer told that she had no illness. It was an annoyance of an evil spirit which had only one remedy for it: bringing a magician and expelling the evil spirit from the body of the girl. As per the instruction from the astrologer they brought the magical ritual performer Puzhiyil Achuthan and decided to conduct the ritual on a new moon day. As part of the ritual, magician Achuthan did Homa and Guruthi. The magician brought all the material for the 
ritual from his home. In the beginning of the ritual, the magician wore a dhoti in the waist of the patient. The climax of the ritual is Guruthi Tharpana [Guruthi is the mixture of lame, turmeric and crysanthus with water]. The magician took a lit and immersed in the oil and lit it. That burning lit was passed over the chest and body and transformed it in to the Guruthi for 108 times. After that, he sprinkled the mixture over the body of the girl. Abruptly, the patient became very unrest and ran around the Homakunda. At that time, the magician told that it was the symptom of the evil spirit leaving the body. The secret of the removal of the evil spirit from the body of the girl is the dhoti which was worn by the magician. The dhoti was arranged in a particular way by the magician. He plucked the pungent chilli from his kitchen garden and made a paste and it put in a bucket and poured water. He immersed the dhoti in it and dried it in the sun. Nobody can identify the effect of pungent chillies with their eyes till the climax of the ritual. Initially, it was not reacting with the body of the girl. But when he sprinkled the Guruthi liquid on her, the dried pungent chilly solution diluted and fell on her body and she felt intolerable burn. It was an invisible action. So the girl and the family thought that the evil spirit had gone away.

\subsection{Dheenamedukkal (To Bring out the Sickness)}

Dheenamedukkal is a usual psychic problem in the women of Kadathanadu region. The situation may be created at the time of the quarrel between the sons and the daughters of a mother or when her husband comes into the home by drinking toddy and scolds her, the patient falls down in the floor crying and rolling. Then she speaks like her ancestors. The treatment for this disease is decided by an astrologer. Usually, the astrologer advises to do magical rituals. Similar situations were experienced in a home at Puthuppanam. During that event, a helper of a magician was presented there. When the patient was rolling on the floor, he tried to remove her dhoti, but she protected herself. It proved that she was acting. Then the helper made a paste of pepper and smeared over his hand and he chanted certain hymns and touched her eyes. Abruptly, she comes into normal state.

\subsection{Maatal Kazhikkal (To Possess)}

Matal Kazhikkal is an important item among the magical rituals. A patient or his relatives usually approaches a local astrologer to solve their problems. The traditional astrologers in the Kadathanadu region are from the Kaniyaan community. Nowadays, the members of all communities are practising astrology. Whether astrologers are traditional or new, they follow same methodology for solving the problem. They communicate with astrological mathematics and find out the problem and advise remedies. Nearly three months ago a magician of Puthuppanam, Puzhiyil Pathmanabhan did a detailed Maatal [Possession] at Thaliparamba in Kannur district. Mr.Pathmanabhan requested the client to avoid him from the ritual but they compelled with love and affection and he agreed to do it. The children of family head are working as medical practitioner and engineer. He thought they were ignoring the magical ritual practised, but the experience is dead against their prediction. They were very co-operative to the ritual with regards and respect. The problem which the patients were experiencing shows certain symptoms. Those who are suffering from serious diseases should get more mental power. Magical rituals are helping strengthen mental power. Those who have mental power can overcome the diseases easily. The incident of Thaliparamba is related to possess, a ghost from the body of the lady of the family. The possessed women will behave benevolently and malevolently. The magician has drew a diagram with five natural colour powder and brought the woman to sit over the diagram [kalam]. He murmured hymns and rang bell simultaneously as he showed the lighted lit over her body nearly108 times and put in the Guruti. He repeated it 64 times. The duration of the ritual was very lengthy. At last, the patient thought that the evil element of her body went away.

\subsection{Charadu Mandrichu Kettal (To Tie a Twine with Magical Power through Chanting Divine Words)}

It is the most common and simplest magical ritual in Kadathanadu region. The patients are mainly children. The process of the ritual is the following: the magician prepares a twine with 28 ties in the same twine. When he ties, he chants divine words. The chanting of words is according to the birth star of the patient. In this magical ritual, the presence of the patient is not needed. Anyone can collect the material from the magician, but one condition: the person who kept the twine is should not make any noise till it is tied on the body of the patient. This twine is not allowed to be watered for three days. The magical ritual practitioners enter into the career with this ritual. 
Usually, magicians in their in their old age can only practice this ritual. It is a livelihood of youngsters and super seniors from their own home without any manual work.

\subsection{Dhoshapani (Sin Deeds)}

This is a symptom of mental disorder. Whenever a person faces a difficult problem or a crisis in his/her life, he/she thinks that it is a wicked action of an enemy. The Dhoshapani is identified in three ways. a) The person who is facing problems identifies the enemy by assumption and approaches a magician and gives the responsibility to him to root out the enemy. b) The client approaches the local astrologer and the astrologer counts the zodiac position with a cowry (small shell used for counting by traditional astrologer) and on the basis of the computation result, the astrologer finds out the enemy. Then the astrologer himself finds out a powerful magician who has the ability to root out the enemy. c) The client directly approached the magician and presents his/her problem. Then the magician through his power with the blessings of his favourite god identifies the enemy and applies remedial actions. The remedies which are done by above three models by the magician in 1960's' as follows

A1. For the solving the problem, the magician does a particular type of magical ritual. The magician plucks out a big elephant yam and writes some devotional words on the surface of the elephant yam by using a thorny prickly shrub. This elephant yam is kept in the premises of the enemy's house. Naturally, the vegetables will rots when it makes a wound. The elephant yam becomes rotten due to the wound by the throne. In a glance, the throne is not identified due to the similarity of the colours of both when the elephant yam gradually rots. At last it is ruined like the process of the elephant yam, the will enemy also expires. That is the belief.

A2. It is a proof that starting magical ritual is folklore due to the versions of rituals done by the same magician in different situations. He used Kaandhanga (lily) instead of elephant yam. Wild onions are tied with yarns and uttering of chant. The same process is repeated as in the case of elephant yam i.e. it is kept underground in the premises of the enemy's house. When it rotten due to the damages made by the twine, they believe that the enemies also rots simultaneously with the lily.

A3. The same process may be repeated with wild onion as done in the previous incident. The folk believe that the magical ritual applied through wild onion is very strong than all other rituals.

A4. Likewise the magician writes some signs over the egg and keeps in the enemy's house. The belief is that the enemies also get ruined as the egg rots.

A5. The magical application on banana: A person who imagines himself, one of the house wives is his lover. To tame her, he approaches a magician and demands to abolish the family life of the lover. The magician tells him, to buy $1 \mathrm{~kg}$ banana and black twine. The magician writes magical signs over banana and ties it with the twine. He tells the client to put it in the well of his lover at midnight. He puts it in the well. Early morning when the husband of his lover takes water from the well, he sees something floating on the water. Then he takes it. The folk around his home is visits and watches the incidents. One eldest among them suggests that it is a sin deeds by a magician, so he should do the remedy. Then he does the remedies through another magician and solves the problem.

A6. Sand applications: This ritual is applied by the magician with sand. First of all take some sands from the footprint of the enemy with the uttering of the chant, the magician dries the sand and puts it in the stove. They believe that the enemy also burned and ruined like sand.

A7. Thakidezhuth [Writing on the metal foil]: Usually, copper foil is used for this writing. According to the financial positions of the patient the writings may be on silver foil. He draws certain symbols on the foil with iron pen and uttering chant. Then gives the metal divine power and keeps it in the premises of enemy's house. It is also worn for self protection. Likewise, to destroy the enemies, the mental patient wears magical metal foil for self protection also. In both cases, most of the patients were wearing copper foil, silver foil and rarely golden foil. The foils are kept in a small container of silver or gold. It should be touched by the body. Sometimes it is worn in the hand, neck or waist. There is a belief that the golden container is not impure, it is a pure one.

A8. Uzhijumaatal (To pass rice and other articles from the top to bottom of the patient): To sit the patient in front of the magician and he take rice in his palm and pass it from the top to bottom of the patient in clockwise direction minimum 21 times and transferred to it into the Guruti (mixture of turmeric powder, lemon and flowers with water) Uzhijumaatal is a particular item in the magical ritual. It may be classified into two.

1) To transfer the enemies negative effect. 
2) To remove the enemies negative effect.

The type No. 1

It is a long magical process. The preparation is necessary for the ritual. The drawing of Sudharsha Chakra by natural colours of rice powder, turmeric powder and lime. The traditional lamp (Nilavilaku), the offerings (Muthircha), the reddish solution made by lime and turmeric (Guruti), lit immersed in oil, and red cloth is necessary for the ritual. The patient is to be seated on the Kalam (floral drawing), the magician take the lighted lid and running the lid all over the body of the patient at 21 times. At last the patient thought that the problem solved by the magician.

The type No. 2

It is affected to the patient by the action of the magician. A slight version of the type one is visible in type. Here bring out the evil spirit from the body of the patient and kept in a material image of either wood, silver or gold. Then it amalgamates to God Vishnu.

Kaivisham edukkal (To bring out poison from the body, which is given or taken in meals).

The concept of Kaivisham is related to food. To destroy the enemy one who supplied poison through food without the knowledge of the patient. Actually it is a psychic problem. It may be explained with an incident. Once an educated boy and girl loved and married without the consent of their family. After her first delivery she was suffering throat pain, she can't swallow even water. She thought this problem is created by her mother in law by giving poison through food. So she is not approached a physician but she approached a magician to removed the poison that was given by her mother in law. The magician keeps her in the magical Kalam and did all rituals at the time of the beginning of the rituals. At the time of the beginning of the ritual the magician keep milk on a vessel. He trickily put a bluish material in it. At the end of the ritual, the colour of the milk changed as blue. On the basis of the transformation of colour of milk, the magician makes aware the patient that the poison was removed from the body. Unfortunately this magical ritual is not effective to the patient. She passed away.

Magical rituals break the border of the religion. Religion is not a hindrance to do the ritual performance. The poozhiyil joint family got the right to do the magical ritual performance by tradition at Angaadithazham and Purangara of Vatakara region. This place is thickly populated by the Muslim community. So the magicians of Poozhiyil Tharavad have done magical rituals each and every Muslim family of the region. The magician was doing all magical rituals except Ganapathi Homam and Sudharshana Homam in the Muslim families. The remuneration for the performance is getting much better than Hindu families. The Muslim people are blind believer of magical rituals than Hindu. Magical ritual is a traditional occupation. Even though the traditional magician were depending up on other occupations.The physician, astrologer, teachers and other government employees were practising magical rituals for a better livelihood. A full time magical performer can maintained the livelihood with the profession itself. So the employees are trying to become an assistant magical performer. This occupation is not a block of doing their main occupation why because the magical ritual is usually performed at night. So this profession is helping for a surplus income. In otherwise the traditional magical performers and the casual magical performers are less in numbers especially among youth. The main reason for the limitation of the youngsters is due to the aura of its anti-progressive nature. More than that, the electrification of every nook and corner of the village also a main hindrance for the performance. Most of the magical ritual performance was done in the shade of darkness. The death rituals related to death, it is transferred through Vishnu temples from houses. The local people are thinking that, by the advice of the astrologer it is better for ritual performances. The administrators of the temple and the other agencies those who are conducting death rituals are influenced by the astrologer and get the chances to a particular temple through agencies. The busy schedule of the life of the people is to be compelled to do the rituals in temples. So the people may remit money in the temple counter and they become satisfied. They think that the duties become over by the remittance of money. The man is wishing to get mental peace whether the magical ritual is to be done in the temple or by a magical ritual performer. But there are certain persons are very particular to do the rituals through a traditional magical performer. So the traditional magical ritual is to be existed in the modern era. Those days the magicians were getting rice, paddy, coconut etc as the remuneration. Later when the Currency becomes popular they got rupees two to five. The helpers get 25 paisa to 1 rupee. Now they got remuneration from the range of 2000 to 5000 . Some times they got more. It depends up on the financial position and recognition of the patients. The people receiving the magician like a VIPs they are preparing high standard food and first class accommodation. Usually the magical ritual is applying to avoid the mental problem of a patient. So it is a practical treatment. Even though magical ritual is considered as an orthodox practical programme among the folk, including the Scientist is demanding the help of 
a magician. The logic, thought and belief is not matching together. Those who are facing the problems they are approaching a magician to overcome the Crisis. The magician themselves understand it is not a reality but through the treatment of chanting, tactics and amulet create an aura of a powerful spirit. It makes success to remove the mental problem.

\section{Conclusion}

Magical Rituals are practised by both upper class and lower class people. It has a traditional methodology. It exists even in the modern society too. The nature of a Magical Ritual is its secrecy. The folk epic "Velamahabharatha" is an oral epic handed over by the ancestors of Vela community. To destroy Pandavas, Dhuryodhana approached Bharatha Malayan to do witchcraft. But the timely involvement of Bharatha Malaya's wife and the application of remedial witchcraft safeguarded Pandavas. This witch craft is known as Nizhalkuthu which means to screw on shadow. This event was utilised by Pannisseri Nanupilla who wrote a script for the art form Kadhakali named as "Nizhalkuthu". The magical performance is the attraction of Kadhakali Nizhalkuthu. The same theme was adopted by cine director Adoor Gopalakrishnan in the Movie Nizhalkuthu. The theme of Magical Ritual is flowing in every walk of life of common folk. Magical Rituals are a reality even today.

\section{References}

[1] Balakrishnan, E. (2014) Payangod-Oru Cheru Dhesham Swayam Adayalappeduthunnu. A.K.G. Smaraka Vayanasala.

[2] Kerala Varma, C.R. (1996) Mandravadhavum Mathavum. Kerala Sahithya Academy, Thrissur.

[3] Vishnu Namboothiri, M.V. (2010) Mandrika Vinjyanam. Mathrubhumi Books, Calicut.

[4] Narayanan, K. (2006) Mandravadham keralathil; Mathrubhumi Books, Calicut.

[5] Nambootiri, K.N. (2006) Magical Ritual and Black Magical Ritual. Panjaagam Publications, Kunnamkulam.

[6] Nambootiripadu, K.S. (2006) Yandravidhikal. 14th Edition, Panjaagam Pusthakasala, Kunnamkulam, Malayalam era 1182 . 